ARTICLE

\title{
Tallking to children: What to do and what not to do
}

\author{
T Brand, BSocSci (SW), MSW (Clinical Practice) \\ Umduduzi Hospice Care for Children, Durban, South Africa
}

Corresponding author: T Brand (tracey@umduduzi.co.za)

Talking to children can be very daunting. Talking to a sick child can be even more daunting. How can we ensure that our message comes across in a way that is suitable and will not cause more harm than good?

S Afr Med J 2014;104(7):510. DOI:10.7196/SAMJ.8429

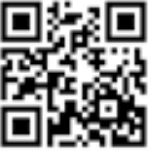

Effective communication with children requires communication styles and behaviours appropriate to the age and cognitive development of the child.

Children effectively speak three languages - body language, play language and spoken language. If you want to speak to children, you need to be proficient in all three.

\section{Body language}

Firstly, be very aware of your own body language. Children are perceptive and often quiet observers. It is easy to almost forget that they are there and watching you. Frowning while reading a file or checking a radiograph will be noted and interpreted, even by a young child. It is very important to be as non-threatening as possible. Get rid of all the 'scary objects', use toys to distract them, be on their level, make eye contact and listen to their responses. Checking your watch and being distracted by parents or a cell phone call will create the impression that you are not interested. Furthermore, observe the child's body language. How and where they are sitting can reveal a great deal about the child's physical and emotional state. Smile with your eyes and your mouth!

\section{Play language}

Children communicate through play, but they may need to be given permission to play in the sterile and sombre healthcare environment. It is useful to have something to occupy them, such as crayons and paper, and play alongside them whenever possible. Be led by the child's 'game' or interaction. Don't try to talk about what you want or need to do. It is hard to imagine a respectable consultant on the floor engaging in a game, but those who dare are able to build strong, trusting relationships with their patients.

\section{Spoken language}

In South Africa, the richness of our cultural diversity means that very often the healthcare provider and child do not speak the same language. Whether you are using a translator or communicating in the child's language, allow yourself to be led by the child. Create an open and safe atmosphere that encourages them to talk. Interrogating the child is hardly likely to be effective. All communication must be conducted in a manner appropriate to the child's level of understanding. This is mostly underestimated by practitioners. Explain, in simple terms, what you are doing without being patronising.

\section{Barriers to communicating with children}

In most healthcare settings, time is the most important barrier to communicating with children because of staff shortages, patient numbers and lack of resources. Being mindful of the child's needs and rights to be involved and showing respect should be part of the daily routine and not be seen as going the extra mile.

I bravely wish to assert that fear is one of the most important barriers to talking to children. Few, if any, healthcare providers feel confident enough to talk to children about illness, particularly when the child is very ill or going to die. We must acknowledge that it is difficult, but not impossible. A supportive team approach can lead to this enormous shift in attitude.

Other barriers to communicating with children include the following:

- appearing judgemental

- being patronising

- interrupting

- second guessing what they are trying to say

- using a commanding voice or tone

- showing displeasure

- not keeping one's word

- arguing

- making promises that one can't or may not be able to keep.

These factors need to be remembered to ensure that we facilitate a meaningful interaction with the children with whom we work.

Breaking down these barriers involves putting the child at ease. This can be done by taking one's time and connecting with them before one launches into one's 'news'. Being sincere when interacting with the child goes a very long way towards breaking down barriers. Respect the child's space - ask their permission before sitting on the side of the bed. If you are a tactile person, touch only when and where appropriate. Remember the three languages and ensure that you are using them. 


\section{Tips for talking to children}

- Take time and don't rush them.

- Listen, listen, listen.

- Be open to talk about anything.

- There is much that children don't know and for which they do not have words.

- Don't interrupt, but wait for the child to finish talking.

- Use language that the child understands, but be careful not to talk down to them.

- Take note of the child's facial expressions and body language.

- Make eye contact and repeat what has been said.

- Ask specific questions that prove you are listening to what they have said.

The best way to find out what children understand and believe is to ask them. By the age of three, children who are dying can mostly understand that they have a serious illness. They can also understand that their illness is worsening, even if no-one tells them, and that death is an inappropriate topic for adults but an appropriate and safe one for children, who are eager to share information. They therefore learn to safely discuss their illness when their parents are not present. Children who have long-term, life-limiting illnesses generally go through various stages of understanding, i.e.:

- I am sick.

- I am sick, but I will get better.

- I am going to keep on getting sick, but I will get better each time I am sick.

- I am going to keep on getting sick and I won't get better.

- I am going to die.

With this in mind, the inclusion of children in discussions about their illness is of paramount importance. In addition, knowing how children of different ages and stages of cognitive development understand concepts such as illness and death is crucial to effective communication in palliative care.

\section{What to do when children ask difficult questions}

- Answer questions with questions. Clarify. Make sure you know exactly what the child is asking before you answer the question. For example, there are many different meanings to the question 'Where do I come from?'. You don't want to be doing the birds-and-the-bees talk when they wanted to know from which country they come!
- Use clear language and avoid euphemisms and jargon.

- Give clear, simple and honest answers to questions.

- Don't go off on a tangent or use too many words.

- Ask if they would like a parent to be present. It is important that the parents have given permission for you to talk to their child, or that you have discussed with them that, if you are asked a question, you will not lie to the child. More often than not the child will ask you questions when the parent is not present because they feel that they need to keep the parent safe. It is important that we facilitate a discussion between the parents and the child if this is the case.

- Check back after explanations.

- Be prepared to say you don't know.

- Don't be scared to show emotion, but tell the child about your emotions so that they do not think that you are angry with them, or sad.

\section{Conclusion}

Talking to children about illness and death need not necessarily be daunting. Children need to be included - they want to be included. It is therefore the responsibility of healthcare providers to find a way of communication that is age appropriate and effective. Ultimately, children have a basic need to be cared for and about: 'I don't care what you think unless I think you care about me!'

\section{Further reading}

Baston J. Healthcare decisions: A review of children's involvement. Paediatr Nurs 2008;20(3):24-26. [http://dx.doi.org/10.7748/paed2008.04.20.3.24.c6517] Coyne I. Consultation with children in hospital: Children, parents' and nurses' perspectives. J Clin Nurs 2006;15:61-71. [http://dx.doi.org/10.1111/j.13652702.2005.01247.x]

Deatrick JA, Woodring BC, Tollefson TL. Children should be seen and heard. Chronically ill children should have a voice in treatment decisions. Health Prog 1990;71:76-79.

Harrisson C, Kenny NP, Sidarous M, Rowell M. Bioethics for clinicians: Involving children in medical decisions. Can Med Assoc J 1997;156:825-828. Shafer A. Who decides for the child? The case of Tyrell Dueck. http:// umanitoba.ca/philosophy/ethics/media/Who_decides_for_the_child.pdf (accessed 22 October 2013).

United Nations. Convention on the Rights of the Child 1989. Geneva: United Nations, 1989. 